\title{
Pengaruh Kegiatan Melukis Dengan Benang Terhadap Perkembangan Kreativitas Anak Usia 5-6 Tahun Di Tk Aisyiyah Bustanul Athfal 06 Medan Bromo
}

\author{
Received : 17 September 2020 Revised : 20 November 2020 Accepted : 24 November 2020
}

\author{
Muhammad Akhir Saputra Daulay ${ }^{1}$, Dorlince Simatupang ${ }^{2}$ \\ Fakultas Ilmu Pendidikan \\ Universitas Negeri Medan \\ Jln. Willem Iskandar Psr V Medan Estate \\ E-mail :mhdakhirdaulay@gmail.com
}

\begin{abstract}
Abstrak. Permasalahan dalam penelitian ini adalah tentang pengaruh kegiatan melukis dengan benang terhadap perkembangan kreativitas anak karena melukis dengan benang bisa meningkatkan perkembangan kreativitas anak, misalnya pada saat anak sedang melakukan kegiatan melukis dengan benang dapat mengembangkan kreativitas. Penelitian ini bertujuan untuk mengetahui pengaruh melukis dengan benang terhadap perkembangan kreativitas anak usia 5-6 tahun di tk aisyiyah bustanul athfal 06 medan bromo tahun ajaran $2018 / 2019$.

Jenis penelitian ini adalah kuantitatif dengan menggunakan metode penelitian eksperimen yaitu penelitian yang bertujuan untuk mengetahui akibat dari sesuatu/ melukis dengan benang yang diberikan kepada subyek/ anak dengan menggunakan quasi exsperimen design bentuk randomized posttest only control group. Penelitian eksperimen ini mengelompokkan sampel penelitian menjadi dua kelompok, kedua kelompok tersebut diberi perlakuan yang berbeda. Pada kelas eksperimen diberi perlakuan pembelajaran menggunakan kegiatan melukis dengan benang, sedangkan pada kelompok kelas kontrol diberi perlakuan pembelajaran dengan menggunakan kegiatan mewarnai.

Data dianalisis dengan teknik statistik deskriptif dengan uji maan whitney (u-test), yang dilanjutkan dengan uji signifikasi pada 0.025 .

Hasil penelitian menunjukkan dengan perlakuan yang berbeda diperoleh skor kreativitas anak kelas eksperimen sebesar 42 sedangkan skor yang diperoleh kelas kontrol sebesar 35. Hal ini terlihat bahwa nilai $\infty / 2=0,05 / 2=0,025$, nilai utabel $\infty=0,025 \mathrm{n} 1=15, \mathrm{n} 2=15$ sehingga diperoleh Zhitung $=-0,03 \leq$ Zhitung $=1,96$ maka kelas eksperimen dengan menggunakan kegitan melukis dengan benang dan kelas kontrol menggunakan kegiatan mewarnai.
\end{abstract}

Kata Kunci: melukis dengan benang, kreativitas anak

\section{PENDAHULUAN}

Kreativitas ialah suatu proses berfikir dalam menciptakan hal yang baru baik itu pendapat atau karya nyata. Kreativitas sangat penting dikembangkan sejak usia dini, dimana pada usia ini anak sangat senang berekplorasi, rasa ingin tahu yang tinggi, dan menyukai aktivitas yang dapat merangsang imajinasinya. Untuk itu peran guru sangat diperlukan dalam pengembangan potensi anak usia 5-6 tahun dan memberi peluang untuk tumbuh kembang bakat dan kreativitas tersebut.

Dalam membantu anak mewujudkan kreativitasnya, guru perlu menciptakan suasana yang dapat merangsang keterampilan kreatif anak sejak dini, dan menyediakan fasilitas pembelajaran dan alat bermain harus menunjang perkembangan kreativitas anak. Hasil 
observasi selama PPL di TK Aisyiyah Bustanul Athfal 06 khususnya dalam pengembangan seni, pada saat guru memberi kegiatan mewarnai gambar yang sudah disediakan guru cenderung menentukan warna yang akan digunakan anak. Jarang diberikan kebebasan kepada anak untuk melakukan kegiatan mewarnai. Guru kurang dapat memberikan suatu kegiatan yang dapat mengembangkan kreativitas anak, guru cenderung mengajarkan anak membaca, menulis dan berhitung, kegiatan yang dilakukan guru cenderung hanya menulis angka, menulis huruf, membaca majalah, dan juga mewarnai majalah. Sebagaimana yang kita ketahui kreativitas sangat penting untuk dikembangkan, oleh karena itu guru hendaknya dapat memberikan suatu kegiatan yang dapat mengembangkan kreativitas anak. Cara yang dapat dilakukan oleh guru dalam mengembangkan kreativitas anak yaitu melalui kegiatan melukis, sehingga dapat membuat anak merasa senang dengan kegiatan tersebut, salah satu kegiatan yang dapat mengembangkan kreativitas anak yaitu melukis, mewarnai.

Melukis dan mewarnai merupakan salah satu kegiatan yang menyenangkan untuk anak di sekolah, dengan kegiatan melukis dan mewarnai anak dapat menuangkan berbagai imajinasinya, untuk melukis dan mewarnai gambar guru harus mengacukannya pada kreativitas dan imajinasi anak. Melukis kurang mendapat perhatian yang serius dari guru, padahal kegiatan melukis dapat mengembangkan kreativitas anak dalam pembelajaran. Dengan kegiatan melukis dengan media benang maka anak sangat senang melakukan kegiatannya. Karena melukis dengan media benang kreativias dan motorik halus anak pun dapat berkembang dengan melakukan kegiatan melukis.

Dengan melukis dapat mengembangkan kreativitas anak, karena ketika membuat lukisan membutuhkan daya kreativitas serta pemilihan warna yang pas sehingga terbentuk suatu lukisan. Melukis dapat berdampak positif bagi perkembangan kreativitas anak, dimana anak dapat berkonsentrasi, mampu mengembangkan kreasinya dan merangsang anak dalam berfikir kreatif.

Pengembangan kreativitas seni rupa anak memiliki tujuan agar anak dapat mengungkapkan perasaan dan pikirannya tertang imajinasi anak tentang diri dan lingkungannya, mengekpresikan diri melalui media kreatif, seperti menggambar dengan arang, melukis dengan cat atau benang, membentuk dengan plastisin, kemampuan mengekpresikan gerak maupun membuat alat music serta menciptakan permainan sendiri dengan pasir, air maupun bermain peran. Melalui kegiatan melukis dengan benang anak dapat berimajinasi, memecahkan masalah yang dihadapi, mengajukan peetanyaan, sehingga perhatiaan anak dalam kegiatan melukis menjadi lebih panjang karena anak berkonsentrasi terhadap kegiatan melukis. Melalui kegiatan melukis dengan benang juga anak dapat menemukan pengalaman baru, imajinasi anak pun dapat berkembang dan dari imajinasinya itu juga merupakan awal dari anak mengaikan ide sehingga akan menghasilkan karya original sebagai bekal anak utuk menjadi pelukis. Jenis melukis yang akan dipelajari disesuaikan dengan karakter anak usia dini, melukis yang dipilih dalam penelitian ini adalah melukis dengan benang karena kegiatan ini belum pernah dilakukan guru, tujuan dari melukis dengan benang sebagai hiburan bagi anak usia dini, dengan menerapkan melukis dengan benang anak diharapkan mampu mengembangkan ide-ide kreatifnya dan membuat anak lebih aktif, serta meningkatkan kreativitas anak khususnya dalam seni lukis.

Pada prinsipnya melukis merupakan cara berkreasi menggunakan peralatan dan teknik yang tak biasa. Cara ini juga disenangi oleh anak karena sifat bermainnya lebih banyak dan anak dapat menginterpretasi bermacam-macam teknik dan mencoba menggabungkan sendiri. Beberapa diantara teknik inkonvensional dalam melukis ini dapat disebutkan 
sebagai berikut : (a) teknik tutup, (b) teknik campur warna kering dan warna basah, (c) melukis dengan teknik gesek benang, (d) melukis dengan teknik ikat-celup, (e) melukis dan menempel, (f) melukis dengan kibasan warna cat air.

Kegiatan melukis bagi seseorang umumnya dapat melalui tiga tahapan yaitu tahap (a) eksplorasi, anda dapat mencari ide dengan berbagai cara, (b) eksperimen atau sering juga disebut tahap mencoba untuk mencari pengalaman, cara yang ditempuh bermacam-macam, (c) kreasi atau menciptakan, pada kegiatan ini anak harus diberi banyak motivasi oleh pendidik sebagai jalan membuka ide dan pemikiran yang baru untuk mencipta.

Bentuk motivasi adalah internal dan eksternal. Motivasi internal adalah dorongan kepada anak dengan menyentuh alam pikiran dan perasaan anak. Hal ini sangat dibutuhkan karena dorongan internal ini akan menumbuhkan alam pikiran yang imajinatif serta memberi dorongan untuk menyeimbangkan pikiran dan perasaan.

Berdasarkan buku Pamadhi, Sukardi (2008: 3.47) Agar pendidik dapat memotivasi anak usia dini untuk melukis, pendidik dapat memberikan model-model berikut : 1) melukis cerita, 2) melukis dengan berdiskusi terlebih dahulu, 3) objek dan isi lukisan, 4) melukis lagu, 5) melukis puisi, 6) melukis gerak dan tarian, 7) melukis kesedihan, 8) melukis kesenangan.

Keberhasilan sebuah lukisan ditentukan oleh faktor atau unsue fisik dan unsur isi. Isi ungkapan dapat terungkap jika pelukisnya dapat berhasil mengelolah dan menyusun unsurunsur fisik menjadi bentuk pernyataan. Berdasarkan buku Mulyani Novi (2017,: 69-70) unsur-unsur dalam seni lukis antara lain : a) Unsur teknik, unsur teknik dalam suatu lukisan adalah unsur yang dapat dilihat dan diraba. Garis, bidang dan warna, bentuk, termasuk proporsi. Melalui imajinasi serta asosiasi unsur-unsur itu diubah menjadi kesatuan tanggapan atau ungkapan perasaan. b) Unsur isi, umumnya gambar karya anak kecil sangat ekspresif, jika kita mencoba mengamati gambar anak kecil secara cermat, kita akan tertarik oleh kewajaran goresan-goresan yang membentuk gambar itu. Setiap unsurnya terjadi dengan tidak dibuat-buat . hal ini disebabkan karena masa kanak-kanak adalah masa fantasi jika mereka melakukan permainan mereka benar-benar menikmati dunia khayalnya.

Selain mempersiapkan perlengkapan kegiatan melukis ini jugamemiliki aturan. Sehingga sebelum melakukan kegiatan melukis diharapkan untuk mengerti dan memahami cara melukis.

Kegiatan mewarnai merupakan kegiatan yang menyenangkan untuk anak. Menyenangkan yang dimaksud di sini terletak pada proses memilih warna yang digunakan untuk mewarnai gambar kosong. Hal tersebut sesuai dengan pendapat Sumanto (2005: 65) bahwa kreativitas yang dapat dikembangkan pada kegiatan mewarnai bagi anak TK adalah adanya kebebasan untuk memilih dan mengkombinasikan unsur warna pada obyek yang diwarnainya sesuai keinginan anak.

Pamadhi, Sukardi (2011: 728) mengatakan "mewarnai pada anak usia dini bertujuan untuk melatih keterampilan, kerapian serta kesabaran". Keterampilan diperoleh dari kemampuan anak untuk mengkordinasi tangan yang dilakukan secara berulang-ulang sehingga semakin lama anak bisa mengendalikan serta mengarahkan sesuai yang dikehendaki. Kerapian dilihat dari bagaimana anak memberi warna pada tempat-tempat yang telah ditentukan semakin lama anak akan semakin terampil untuk menggoreskan media pewarnanya karena 
sudah terbiasa. Kesabaran diperoleh melalui kegiatan memilih dan menentukan komposisi yang tepat sesuai pendapatnya seberapa banyak warna yang digunakan untuk menentukan komposisi warnanya. Usaha yang dilakukan secara terus-menerus akan melatih kesabaran anak.

Berdasarkan beberapa pendapat yang telah disampaikan di atas dapat disimpulkan bahwa kegiatan mewarnai merupakan kegiatan yang sangat cocok diterapkan untuk anak usia taman kanak-kanak, karena mewarnai merupakan kegiatan yang menyenangkan. Selain itu, melalui kegiatan mewarnai dapat melatih keterampilan anak dengan hasil mewarnai anak yang tidak keluar dari garis, kerapian yang dibuktikan dengan hasil mewarnai yang rapi, dan kesabaran dibuktikan dengan anak yang sabar ketika mewarnai gambar serta mengekspresikan keinginannya untuk membuat warna pada gambar menggunakan pewarna

\section{METODOLOGI PENELITIAN}

Jenis penelitian yang digunakan dalam penelitian ini adalah jenis penelitian kuantitatif (eksperimen). Populasi dalam penelitian ini adalah seluruh anak kelompok B di TK Asyiyah Bustanul Athfal 06 dengan jumlah 45 orang yang terdiri dari 3 kelas yaitu kelas angrek 15 orang, kelas anggrek 15 orang, kelas melati 15 orang.

Tabel 1. Kisi-Kisi Kreativitas Anak

\begin{tabular}{|c|c|c|c|c|}
\hline No & Variabel & Indikator & Deskriptor & $\begin{array}{l}\text { No } \\
\text { Butir }\end{array}$ \\
\hline 1 & & $\begin{array}{l}\text { Mempunyai } \\
\text { inisiatif }\end{array}$ & $\begin{array}{l}\text { 1. Anak mampu mengeluarkan } \\
\text { gagasan baru } \\
\text { 2. Anak mampu melakukan } \\
\text { tindakan berbeda dari } \\
\text { temannya } \\
\text { 3. Anak mampu menghasilkan } \\
\text { karya yang berbeda }\end{array}$ & 1 \\
\hline 2 & Kreativitas & $\begin{array}{l}\text { Bersifat ingin } \\
\text { tahu }\end{array}$ & $\begin{array}{l}\text { 1. Anak jarang bertanya tentang } \\
\text { tertang kegiatan } \\
\text { 2. Anak sering bertanya pada } \\
\text { saat kegiatan } \\
\text { 3. Anak selalu bertanya pada } \\
\text { saat kegiatan }\end{array}$ & 2 \\
\hline 3 & & Penuh semangat & $\begin{array}{l}\text { 1. Anak mampu belajar sendiri } \\
\text { 2. Anak mampu menyelesaikan } \\
\text { tugasnya } \\
\text { 3. Anak mampu berkreasi } \\
\text { sendiri }\end{array}$ & 3 \\
\hline
\end{tabular}

Keterangan:

Memberi skor pada butir-butir kreativitas anak, diberi check list pada kolom no butir $(1,2$, dan 3) sesuai dengan kriteria berikut :

Nilai 3 jika deskriptor 3 yang muncul

Nilai 2 jika deskriptor 2 yang muncul

Nilai 1 jika deskriptor 1 yang muncul 


\section{HASIL DAN DISKUSI}

Lembar observasi di rancang sedemikian rupa, supaya dapat digunakan untuk mengamati data perkembangan kreativitas anak di kelompok B. Perlakuan yang diberikan untuk mengetahui perkembangan kreativitas adalah dengan kegiatan melukis dengan benang. Pada kelompok eksperimen menerapkan melukis dengan benang menggunakan peralatan benang wol, kertas A4, pewarna makanan dan pada kelompok kontrol menerapkan kegiatan mewarnai tidak menggunakan alat krayon di Tk Aisyiyah Bustanul Athfal 06 Bromo Medan. Dengan menemui kepala sekolah yakni Tengku Sri Dewi S.Pd.I untuk mendapatkan izin memasuki kelas angrek dan kelas melati sebagai kelas eksperimen dan kelas kontrol. Analisis yang dilakukan untuk mengolah data pada penelitian ini dianalisis dengan menggunakan teknik analisis statitic non parametrik dengan menggunakan Uji Mann Whitney. Selanjutnya data ini diolah dengan tahapan menghitung data hasil post test kelas eksperimen dan kelas kontrol, menghitung data kelas eksperimen dan kelas kontrol menggunakan uji mann whitney, membuat tabel penolong uji mann whitney, dan mencari perbedaan antara Zhitung dan Ztabel.

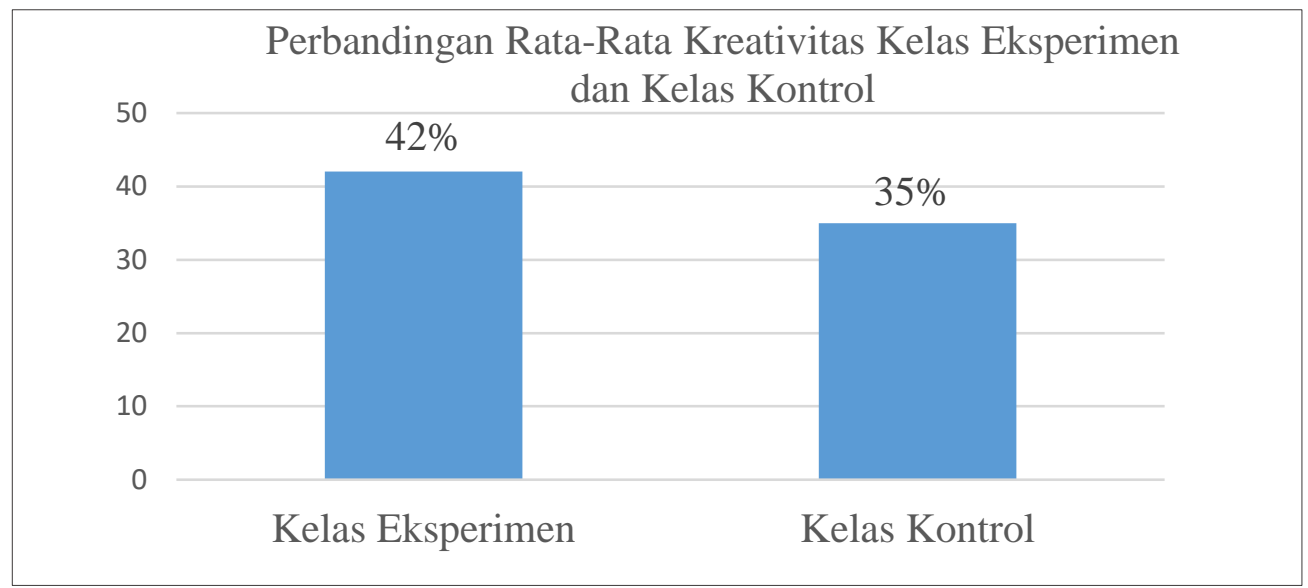

\section{Gambar 1. Perbandingan Perkembangan Kreativitas Anak Kelas Eksperimen Dan Kelas Kontrol}

Dari data gambar diagram batang diatas menunjukkan bahwa setelah dilakukan penghitungan hasil rata-rata perkembangan kreativitas menggunakan kegiatan melukis dengan benang dengan pencapaian yaitu $42 \%$. Selanjutnya untuk kegiatan mewarnai dikelas kontrol memperoleh nilai rata-rata 35\%. Sehingga diperoleh perbandingan antara kelas eskperimen dengan kategori baik sekali dan kelas kontrol dengan kategori baik. Penjelasan pemerolehan data hasil rata-rata perkembangan kreativitas anak usia 5-6 tahun di TK Aisyiyah Bustanul Athfal 06 Medan Bromo.

\section{PEMBAHASAN}

Pada proses dalam memperoleh hasil analisis data, sebelum memberikan perlakuan yang berbeda-beda dari dua kelas, maka sampel yang ditentukan adalah kelas eksperimen dan kelas kontrol sehingga perkembangan kreativitas anak adalah sama yakni berdasarkan tingkat usia kelas eksperimen dan kelas kontrol yaitu masing-masing usia 6 tahun.

Setelah dilakukan perlakuan yang berbeda diperoleh perkembangan kreativitas anak kelas eksperimen (Anggrek) menggunakan kegiatan melukis dengan benang menggunakan 
benang wol dan pewarna maka diperoleh hasil sebesar 42. Moeclichatoen (dalam jurnal Utami 2014:10) bahwa melalui kegiatan bermain seni (melukis), anak dapat mengembangkan kreativitasnya, melalui kegiatan-kegiatan kelenturan, ekspresi diri dan imajinasi, kegiatan pemecahan masalah, dan mencari cara untuk mencampur warna dan melukis, maka secara tidak sadar anak sedang belajar dan stimulasi melalui media seni rupa melukis. Selain itu kegiatan mewarnai dapat mempengaruhi perkembangan kreativitas anak terutama di kelas eksperimen dengan adanya kegiatan melukis dengan benang bisa mengembangkan perkembangan kreativitas anak Sedangkan dikelas kontrol melati menggunakan kegiatan mewarnai maka diperoleh hasil sebesar 35.

Dari hasil post test kedua sampel tersebut terdapat perbedaan yang signifikan antara perkembangan kreativitas anak pada kelas eksperimen anggrek dengan kelas kontrol melati

\section{SIMPULAN}

Berdasarkan hasil penelitian yang telah dilakukan, maka dapat disimpulkan bahwa :

1) Ada perbedaan yang signifikan antara kelas yang melakukan kegiatan melukis dengan benang dan kelas yang melakukan kegiatan mewarnai pada anak usia 5-6 tahun.

2) Ada pengaruh yang signifikan antara kegiatan melukis dengan benang terhadap perkembangan kreativitas anak usia 5-6 tahun di TK Aisyiyah Bustanul Athfal 06 Medan Bromo.

3) Melalui kegiatan melukis dengan benang dapat memberikan suasana bermain seraya belajar, dan membuat anak semakin antusias dalam melakukan kegiatan melukis dengan benang.

Berdasarkan pembahasan dan kesimpulan yang telah dikemukakan diatas maka peneliti memberikan beberapa saran sebagai berikut :

1) Bagi guru sebaiknya lebih terampil dalam melakukan kegiatan pembelajaran yang menarik kegiatan melukis dengan benang.dan bervariasi khususnya dalam mengembangkan kemampuan kreativitas dengan menggunakan melukis dengan benang.

2) Bagi anak diharapkan melalui kegiatan melukis dengan benang dapat mengembangkan kreativitas anak dan dapat mengembangkan motorik halus anak.

3) Bagi peleliti selanjutnya yang ingin meneliti lebih lanjut hendaknya terus berupaya untuk menambah pengetahuan dan memperluas wawasan tentang kegiatan melukis dengan benang terhadap perkembangan kreativitas anak.

4) Bagi penulis dapat menambah pengetahuan tentang betapa pentingnya melukis dengan benang terhadap mengembangkan kreativita anak, dapat mengembangkan kemampuan dan keterampilan/ menambah pengalaman. 


\section{DAFTAR RUJUKAN}

Kurniati, E dan Rachmawati, Y. 2010. Strategi Pengembangan Kreativitas Pada Anak. Jakarta: Kencana.

Marjukah. 2012. Peningkatan Kreativitas Anak Melalui Kegiatan Melukis Pada TKIT Alhasnah Kebonarum Klaten Kelompok B2

Mulyani, Novi. 2017. Pengembangan Seni Anak Usia Dini. Bandung : Remaja Rosdakarya.

Munandar, Utami. 2014. Pengembangan Kreativitas Anak Berbakat. Jakarta: Rineka Cipta.

Noor Juliansyah.2012. Metodologi Penelitian : Skripsi, Tesis, Disertasi, Dan Karya Ilmiah. Jakarta: Prenadamedia Group.

Pamadhi dan Sukardi. (2008). Seni Keterampilan Anak. Jakarta: Universitas Terbuka

Siregar, Syofian. 2017. Statistika Terapan Untuk Perguruan Tinggi. Jakarta: Kencana

Sugiyono. 2010. Metode penelitian kuantitatif, kualitatif, dan R \& D. Bandung: Alfabeta.

Sumanto. 2005. Pengembangan Kreativitas Senirupa Anak TK. Jakarta: Depertemen Pendidikan Nasional Jenderal Pendidikan Tinggi Direktorat Pembinaan Pendidikan Tenaga Kependidikan Dan Ketenagaan Perguruan Tinggi.

Susanto, Ahmad. 2011. Perkembangan Anak Usia Dini. Jakarta: Kencana

Trisnahayu. 2014. Meningkatkan Kreativitas Seni Anak Melalui Permainan Warna Dengan Media Benang Pada Anak Kelompok B Paud Nurul Amal Desa Batungan Kecamatan Kedurang Ilir Kabupaten Bengkulu Selatan.

Utami. 2014. Pengaruh Melukis Terhadap Kreativitas Seni Anak Usia Dini Di TK 02 Buran Tasikmadu karanganyar. 